University of Nebraska - Lincoln

DigitalCommons@University of Nebraska - Lincoln

Papers in the Earth and Atmospheric Sciences Earth and Atmospheric Sciences, Department

2000

\title{
Clay Mineral Composition of Glacial Erratics, McMurdo Sound
}

\author{
Mary Anne Holmes \\ University of Nebraska-Lincoln, mholmes2@unl.edu
}

Follow this and additional works at: https://digitalcommons.unl.edu/geosciencefacpub

Part of the Earth Sciences Commons

Holmes, Mary Anne, "Clay Mineral Composition of Glacial Erratics, McMurdo Sound" (2000). Papers in the Earth and Atmospheric Sciences. 79.

https://digitalcommons.unl.edu/geosciencefacpub/79

This Article is brought to you for free and open access by the Earth and Atmospheric Sciences, Department of at DigitalCommons@University of Nebraska - Lincoln. It has been accepted for inclusion in Papers in the Earth and Atmospheric Sciences by an authorized administrator of DigitalCommons@University of Nebraska - Lincoln. 


\title{
CLAY MINERAL COMPOSITION OF GLACIAL ERRATICS, MCMURDO SOUND
}

\author{
Mary Anne Holmes \\ Department of Geosciences University of Nebraska-Lincoln, Lincoln, NE
}

\begin{abstract}
Twenty-two erratics collected from coastal moraines along the shores of Mount Discovery, Brown Peninsula, Minna Bluff, on Black Island, and from the Salmon and Miers valley floors in East Antarctica were examined for their mineral composition in the $<2 \mathrm{~m}$ fraction by $\mathrm{x}$-ray diffraction to determine their provenance and the climate under which the sediment in the erratics formed. Semi-quantitative results from peak areas were subjected to principal components analysis and indicate that there are two distinct mineral compositions in the erratics $(c=0.05)$ : A) dominant smectite group minerals, minor illite and kaolinite, and no chlorite, and B) dominant illite, subordinate smectite group, and either chlorite and $R=1 \mathrm{I} / \mathrm{S}$ clay or $\mathrm{R}=3 \mathrm{I} / \mathrm{S}$ clay. Group A erratics include two types: 1 ) Eocene age siliciclastic sediment and 2) volcaniclastics of unknown age. Group B erratics comprise three types: 1) Eocene age siliciclastic sediment dominated by illite with subordinate smectite, no chlorite, and very low levels of kaolinite and mixed-layer clays; 2) post Eocene age erratics dominated by illite with a major component of chlorite and $\mathrm{R}=1 \mathrm{I} / \mathrm{S}$ clay, minor or no smectite and kaolinite; and 3) post Eocene age erratics dominated by illite and containing $R=3 \mathrm{I} / \mathrm{S}$ clay. Eocene age sediment occurs in either group and so had two distinct provenances for the clay fraction: a smectite-dominant area and an illite-rich, smectite-poor area. Post Eocene age sediment also had two distinct provenances for the clay fraction and are different from the Eocene sources: a metamorphic + ancient sedimentary terrain that supplied chlorite, illite, and $R=1 \mathrm{I} / \mathrm{S}$ clay to some of the erratics, and a sedimentary terrain that supplied illite and $\mathrm{R}=3 \mathrm{I} / \mathrm{S}$ clay. Kaolinite levels are low, indicating the absence of intense weathering and/or any significant contribution from the Beacon Supergroup.
\end{abstract}

\section{INTRODUCTION}

A team of University of Nebraska-Lincoln geologists collected over one hundred glacial erratics from coastal moraines along the shores of Mount Discovery, Brown Peninsula and Minna Bluff, as well as from moraine on Black Island and along the floors of Salmon and Miers valleys in Antarctica [Levy and Harwood, this volume; see their Figure 1] during three field seasons (1992-1995) in an effort to learn more about the Paleogene history of East Antarctica. The erratics were analyzed for siliceous microfossil content, palynomorphs, and lithofacies, and the findings are discussed in Levy and Harwood [this volume], and Bohaty and Harwood [this volume]. The clay mineral compositions of 22 selected erratics were examined for this study to provide a representative of each lithotype identified by Levy and Harwood [this volume] in order to determine if the clay composition could shed 
any light on the climatic conditions that prevailed when the sediment in the erratics was originally deposited.

Provided the clays are detrital, some climatic significance may be gleaned from their occurrence, particularly in sediments formed at high latitudes [Ehrmann et al., 1992; Ehrmann, 1996]. Among the most common clays, chlorite and ordered mixed-layer clays do not survive much weathering and transport by water [e.g., Chamley, 1989]. Their abundant presence in sediments thus indicates a cool and/or dry climate. Smectite forms under more humid conditions, especially when there is a readily soluble precursor, such as volcanic ash or basalt [e.g., Biscaye, 1965; Nadeau and Reynolds, 1981]. Pedogenic kaolinite forms in the wettest and warmest climate among the detrital clays. Illite is a poor climatic indicator. It is apparently principally derived from Paleozoic or older shales, in which diagenesis has formed illite from smectite and nonclay precursors. It can survive temperate and even subtropical weathering conditions.

Abundant chlorite and/or ordered, mixed-layer clays in the $<2 \mathrm{~m}$ fraction of these erratics would indicate that the sediment initially formed under cool and/or dry conditions, and has not been subjected to significant weathering at any time in its subsequent history. The presence of smectite and/or kaolinite would indicate significant weathering at some time during the erratic's history. Presumably this weathering would have occurred during a period of nonglacial (excluding montane glaciation) conditions in East Antarctica.

The purpose of this study was to determine the clay mineral composition of glacial erratics collected in East Antarctica in an effort to learn the intensity of the weathering regime under which the sediment in the clasts formed, which may assist in the determination of their ages and environments of deposition.

\section{METHODS}

\section{Sample Preparation and Diffraction Analysis}

Erratics were collected during three field seasons from Minna Bluff, Mount Discovery, and sea ice moraine near McMurdo station [see Levy and Harwood, this volume for collection and locality details]. Twenty-two of these were selected for clay mineral analysis to represent the major lithotypes identified by Levy and Harwood [this volume]. These were soaked in distilled water and dispersed in sodium hexametaphosphate solution, treated with the ultrasound for 3-4 minutes, and centrifuged to remove the $<2 \mathrm{~m}$ fraction for examination [Jackson, 1975]. This fraction was decanted into a Millipore filtra- tion apparatus and an oriented mount prepared after the method of Drever [1973]. Oriented mounts were x-rayed using a Scintag PAD V x-ray diffractometer equipped with a graphite monochromator and $0.67^{\circ}$ and $0.76^{\circ}$ divergence slits on either side of a collimator. Oriented samples were scanned from $2^{\circ}$ to $45^{\circ} 2$ in the air-dried state, from $2^{\circ}$ to $30^{\circ} 2$ after ethylene glycol solvation $\left(60^{\circ} \mathrm{C}\right.$ over ethylene glycol vapor in a desiccator overnight), and from $2^{\circ}$ to $15^{\circ} 2$ after heating to $350^{\circ} \mathrm{C}$ for one hour in a muffle furnace. Peak areas and positions were calculated from the glycolated scans using the unweighted split Pearson model in the Profile Fitting package of Scintag's DMS software, v. 3.1.

\section{Mineral Identification and Semi-Quantification}

Mineral identification followed standard methods. Kaolinite and chlorite were distinguished by the slow scan method of Biscaye [1964] over the 004 peak of chlorite and the 002 peak of kaolinite. Where these peaks were too small to allow an accurate position, the 002 peak of chlorite and the 001 peak of kaolinite were used. This assumes that a peak position of $7.10 \AA$ indicates chlorite and $7.16 \AA$ indicates kaolinite [Biscaye, 1964]. Illite and mixed-layer clays were identified from diffractograms of samples treated with ethylene glycol by referring to Reynolds [1980], Moore and Reynolds [1989], and the ${ }^{\circ}$ 2 method of Srodon [1980]. In brief, for glycolated samples, any peak at $16-17 \AA$ was identified as $R=0 \mathrm{I} / \mathrm{S}$ clay ("randomly interstratified"); a peak near $12-13 \AA$ as $\mathrm{R}=1$ I/S clay ("I/S ordered"), and a low-angle shoulder on the $10 \AA$ illite peak near $11 \AA ̊$ as R=3 I/S clay ("ISII ordered"). In addition, peak positions for $002 / 003 \mathrm{I} / \mathrm{S}$ peaks between $15^{\circ}-20^{\circ} 2$ were calculated using the profile fitting software. A peak at $5.0 \AA$ was used to identify the presence of illite where no $11 \AA$ shoulder occurred on the $10 \AA$ peak. Had a shoulder appeared, this peak might indicate $\mathrm{R}=3$ $\mathrm{I} / \mathrm{S}$ clay. Peaks between 5.2 and $5.34 \AA$ were identified as $\mathrm{R}=1 \mathrm{I} / \mathrm{S}$ clay, and peaks between 5.4 and $5.6 \AA$ were identified as $\mathrm{R}=0 \mathrm{I} / \mathrm{S}$ clay. Where possible, the presence of both $001 / 002$ and $002 / 003 \mathrm{I} / \mathrm{S}$ peak positions were used to obtain a ${ }^{\circ} 2$ value [Srodon, 1980], from which \% nonexpandable layers was calculated from values published in Moore and Reynolds [1989]. Non-clay mineral identification also followed standard methods as outlined in Brown [1980]. Plagioclase was distinguished from potassium feldspars by the method of Borg and Smith [1969]; opal-CT was identified after Jones and Segnit [1971].

Semi-quantitative results were calculated for clay minerals from profile fit-derived peak areas using the weighted method of Biscaye [1965]. This method was 
tested on this instrument by the use of a pyrophyllite internal standard [Heiden and Holmes, 1998]. The two methods agree nearly perfectly (confidence level for correlation coefficient $=0.95$ ). The overall error for any particular clay for this method is unknown, but repeated tests indicate it is internally consistent. Other workers estimate an error for xrd-derived results at around $10 \%$ [e.g., Moore and Reynolds, 1989].

The semi-quantitative results were subjected to principal components analysis, using Systat v. 5.0, with an Eigenvalue of 1.000 and varimax rotation, in an effort to see if the number of variables might be reduced.

\section{RESULTS}

Smectite group minerals occur in all but four of the samples (Tables 1 and 2) and vary from minerals that give large, sharp peaks (Figure 1a), to small, sharp peaks (Figures $1 \mathrm{~b}$ and 1c), to small, broad peaks (Figures $1 \mathrm{~d}$ and 1e). Twelve samples contain chlorite (e.g., Figures 1b, 1c, and 1e), and all but two samples contain illite (e.g., Figures 1a-1c and 1e). Nine samples contain kaolinite (Table 1, Figures 1a and 1d). Eight samples contain $\mathrm{R}=1$ $\mathrm{I} / \mathrm{S}$ clay (Table 1 , Figures $1 \mathrm{~b}$ and $1 \mathrm{c}$ ), and only three contain $\mathrm{R}=3 \mathrm{I} / \mathrm{S}$ clay (Table 1, Figure 1e). Most contain quartz (Figures 1a, 1b, 1c and 1e), and about half contain generally small amounts of potassium feldspar and/or plagioclase (Figures 1b-1e). Minor components, identified in only a few samples, include a zeolite at around $9 \AA$ (Figure 1b), possibly of the clinoptilolite-heulandite series, amphiboles (sharp peak at around 8 to $8.4 \AA$, Figure 1c), and opal-CT in one sample (Figure 1b).

Semi-quantitative results based on peak areas of clays in individual samples (Table 2) were subjected to principal components analysis. Two factors explain $91.6 \%$ of the variance in the data set. Factor loadings indicate that factor 1 causes samples to be enriched either in smectite, or in illite (Table 3). The second factor apparently causes enrichment in chlorite and $\mathrm{R}=1 \mathrm{~V} / \mathrm{S}$ clay or, conversely, in $\mathrm{R}=3 \mathrm{I} / \mathrm{S}$ clay. From these results, the sam-

\begin{tabular}{|c|c|c|c|c|c|c|c|c|c|c|}
\hline Sample & smectite & $R=1 \mathrm{I} / \mathrm{S}$ & $R=3 \mathrm{I} / \mathrm{S}$ & chlorite & illite & kaolinite & quartz & k-spar & plag & others \\
\hline E145 & $\mathrm{X}, \mathrm{s}$ & $\mathbf{x}$ & & & $\mathrm{x}$ & $\mathrm{x}$ & $\mathrm{X}$ & $\mathrm{x}$ & $\mathrm{X}$ & \\
\hline E219 & $\mathrm{X}, \mathrm{S}$ & & & $\mathrm{x}$ & $\mathrm{X}$ & & $\mathbf{x}$ & & $\mathrm{x}$ & \\
\hline E242D & $\mathbf{X}, \mathrm{b}$ & $\mathbf{x}$ & & $\mathbf{x}$ & $\mathrm{x}$ & & $\mathrm{x}$ & $\mathbf{x}$ & $\mathbf{x}$ & amphibole \\
\hline E243 & & $\mathbf{x}$ & & $\mathbf{x}$ & $\mathrm{x}$ & & $\mathrm{X}$ & $x$ & $\mathrm{X}$ & \\
\hline E317 & $\mathrm{X}, \mathrm{S}$ & & & & $\mathrm{X}$ & $x$ & $\mathbf{x}$ & & & \\
\hline E323 & & $\mathbf{X}$ & & $\mathrm{X}$ & $\mathbf{x}$ & & & & & \\
\hline E347 & & & & $\mathrm{x}$ & $\mathrm{x}$ & & $\mathrm{X}$ & $x$ & $\mathrm{x}$ & amphibole \\
\hline E360 & & & $\mathrm{x}$ & $\mathbf{x}$ & $\mathrm{x}$ & & $\mathrm{X}$ & $x$ & $\mathrm{x}$ & zeolite \\
\hline E363 & $\mathrm{X}, \mathrm{s}$ & $\mathbf{x}$ & & $\mathbf{x}$ & $\mathrm{X}$ & & $\mathbf{x}$ & $x$ & $\mathrm{x}$ & opal-CT, zeolite \\
\hline MB80 & $\mathrm{X}, \mathrm{s}$ & & & & $\mathrm{X}$ & & & & & zeolite \\
\hline MB 181 & $\mathrm{X}, \mathrm{S}$ & & & & $\mathbf{x}$ & $\mathrm{x}$ & & $\mathrm{x}$ & & \\
\hline MB202 & $\mathrm{X}, \mathrm{b}$ & & & & & $\mathrm{x}$ & $\mathrm{x}$ & $\mathbf{x}$ & $\mathbf{x}$ & \\
\hline MB212K & $\mathrm{X}, \mathrm{s}$ & & & $\mathrm{X}$ & $\mathrm{X}$ & & $\mathrm{X}$ & $\mathbf{x}$ & $\mathrm{x}$ & amphibole \\
\hline MB217A & $\mathrm{X}, \mathrm{s}$ & $\mathbf{x}$ & & $\mathbf{x}$ & $\mathrm{x}$ & $\mathrm{x}$ & $\mathrm{X}$ & $\mathrm{X}$ & $\mathrm{x}$ & amphibole, zeolite \\
\hline MB235A & $\mathbf{X}, \mathbf{b}$ & & $\mathrm{X}$ & $\mathrm{X}$ & $\mathrm{X}$ & & $\mathrm{X}$ & & $\mathrm{x}$ & \\
\hline MTD42 & $\mathrm{X}, \mathrm{S}$ & & & & $\mathrm{x}$ & $\mathrm{x}$ & $\mathbf{x}$ & & & \\
\hline MTD153 & $\mathrm{X}, \mathrm{s}$ & $\mathbf{x}$ & & & $\mathrm{x}$ & $\mathbf{X}$ & & & & \\
\hline MTD154 & $\mathrm{X}, \mathrm{b}$ & & & & $x$ & $\mathbf{x}$ & $\mathrm{x}$ & & & \\
\hline MTD190 & $\mathrm{X}, \mathrm{b}$ & & & & $\mathbf{x}$ & $\mathrm{x}$ & $\mathrm{x}$ & & & \\
\hline SIM5 & $\mathrm{X}, \mathrm{s}$ & $\mathbf{x}$ & & $\mathrm{X}$ & $\mathbf{x}$ & & $\mathbf{x}$ & $\mathrm{x}$ & $x$ & \\
\hline SIM11 & $\mathbf{X}, \mathrm{b}$ & & $\mathbf{X}$ & & & & & & & \\
\hline SV12 & $\mathrm{X}, \mathrm{b}$ & & & $\mathbf{X}$ & $\mathbf{X}$ & & $\mathrm{X}$ & & $\mathrm{X}$ & amphibole \\
\hline
\end{tabular}


Table 2. Semi-quantitative results on clay minerals of the $<2 \mu \mathrm{m}$ fraction of glacial erratics, based on profile fit-derived peak areas and Biscaye's (1965) weight factors.

\begin{tabular}{crrrrrrr}
\hline Sample & smc & chlor & R $=1$ I/S & R=3 I/S & \multicolumn{1}{l}{ ill } & kao \\
\hline E145 & 68 & 0 & 6 & 0 & 16 & 10 \\
E219 & 68 & 10 & 0 & 0 & 22 & 0 \\
E242D & 36 & 17 & 12 & 0 & 36 & 0 \\
E243 & 0 & 13 & 15 & 0 & 73 & 0 \\
E317 & 92 & 0 & 0 & 0 & 5 & 3 \\
E323 & 0 & 38 & 5 & 0 & 56 & 0 \\
E347 & 0 & 8 & 0 & 0 & 92 & 0 \\
E360 & 0 & 8 & 0 & 21 & 71 & 0 \\
E363 & 10 & 7 & 27 & 0 & 55 & 0 \\
MB80 & 25 & 0 & 0 & 0 & 75 & 0 \\
MB181 & 63 & 0 & 0 & 0 & 33 & 4 \\
MB202 & 91 & 0 & 0 & 0 & 0 & 9 \\
MB212K & 50 & 14 & 0 & 0 & 36 & 0 \\
MB217A & 18 & 6 & 7 & 0 & 67 & 3 \\
MB235A & 19 & 4 & 0 & 34 & 43 & 0 \\
MTD42 & 73 & 0 & 0 & 0 & 24 & 3 \\
MTD153 & 33 & 0 & 13 & 0 & 52 & 3 \\
MTD154 & 44 & 0 & 0 & 0 & 52 & 4 \\
MTD190 & 65 & 0 & 0 & 0 & 30 & 5 \\
SIM5 & 30 & 12 & 18 & 0 & 40 & 0 \\
SIM11 & 90 & 0 & 0 & 10 & 0 & 0 \\
SV12 & 82 & 10 & 0 & 0 & 8 & 0 \\
\hline
\end{tabular}

ples appear to fall into two groups which differ in each clay component at the 0.05 confidence level (Table 4). The first, designated 'Group A', has a consistent mineral composition characterized by dominant smectite levels $(>60 \%$ ), higher levels of kaolinite than the other group of samples, and lower levels of the other four clay minerals (Table 4). The second, designated 'Group B', is a more diverse group of samples as indicated by higher standard deviations for all mineral components. The dominant clay in this group is illite. These samples have, on average, higher levels of chlorite and $\mathrm{R}=1 \mathrm{I} / \mathrm{S}$ clays. The differences are statistically significant at the 0.05 confidence level (based on student's t-tests) for all mineral components except the $\mathrm{R}=3 \mathrm{I} / \mathrm{S}$ clays (Table 4).

\section{DISCUSSION}

\section{Authigenic vs. Detrital Origin of the Minerals}

Clays occurring in sediments may be detrital or authigenic, which may be determined from x-ray diffraction by peak sharpness (generally sharp for authigenic minerals), thin section petrography, and scanning electron microscopy [Wilson and Pittman, 1977]. Authigenic minerals reflect the physico-chemical conditions of diagenesis under which they form. Among the minerals identified in this study, opal-CT in Erratic E363 (Figure 1b) is most probably an alteration product of biogenic opal [Jones and Segnit, 1971; Kastner et al., 1977]. This erratic is a marine mudstone with ostracodes and dropstones [Levy and Harwood, this volume]. In addition, four samples contain sharp smectite group mineral peaks that may indicate an authigenic component: E219, E317, MB181, and MTD42. Photomicrographs of thin sections do not indicate the presence of authigenic clays [Levy and Harwood, this volume]. All four of these erratics were dated using palynomorphs as middle to late Eocene in age [Bohaty and Harwood, this volume]. They represent four different lithofacies: E219 is a massive, sandy, bioturbated mudstone with a leaf fossil; E317 is a poorly sorted, massive sandstone with abundant feldspar and granite clasts; MB181 comprises graded sand and pebbles; and MTD 42 is a massive, matrix-supported conglomerate. Based on petrography, these sharp-peaked smectite group minerals are assumed to be detrital. None of the other clay or nonclay minerals appear to be authigenic, based on petrography [Levy and Harwood, this volume].

\section{Significance of Detrital Clays}

Where clays are established to be detrital in origin, they are generally assumed to be derived from the soils in which they formed, and hence, are indicators of the climatic regime from which they were derived [e.g., Chamley, 1989]. However, detrital clays may also be derived from older, exposed and eroding sediment, and the relative contribution of soils and pre-existing sediment to any sedimentary basin remains problematic when

Table 3. Factor score coefficients, factors 1 and 2 , from principal components analysis on the results from Table 2 , varimax rota-tion. These two factors explain $91.6 \%$ of the variance in the data set.

\begin{tabular}{lrrr}
\hline & Factor 1 & Factor 2 & Factor 3 \\
\hline Illite & 0.922 & -0.04 & 0.157 \\
$\mathrm{R}=1$ & 0.511 & 0.615 & 0.123 \\
$\mathrm{R}=3$ & 0.186 & -0.884 & 0.048 \\
Chlorite & 0.137 & 0.211 & 0.889 \\
Kaolinite & -0.313 & 0.236 & -0.775 \\
Smectite & -0.922 & 0.04 & -0.348 \\
\hline
\end{tabular}



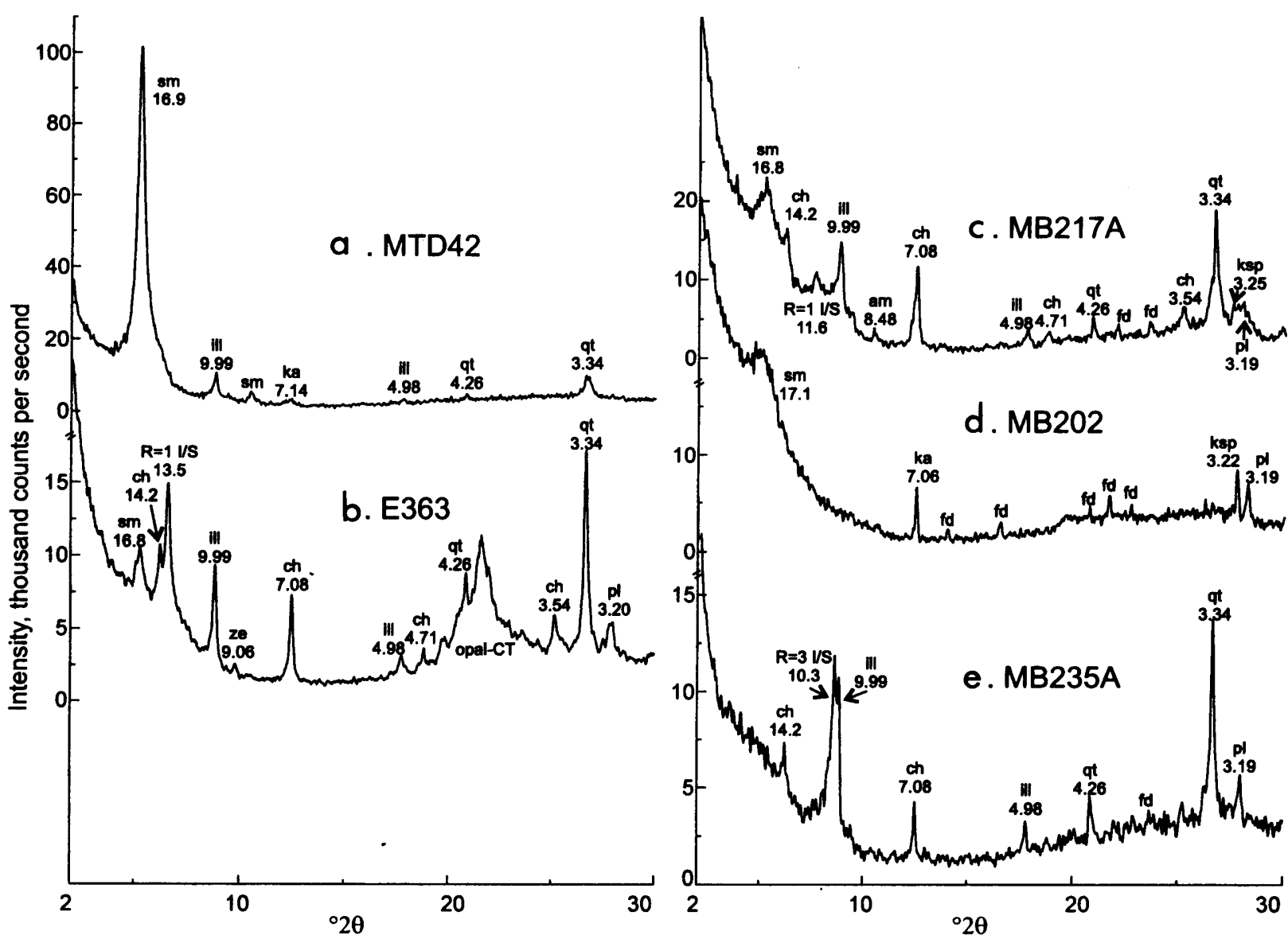

Figure 1. Selected diffractograms of ethylene glycol-treated, $<2 \mathrm{~m}$ fraction of glacial erratics. The ordinate axis is intensity in thousands of counts per second. Number over peaks are d-spacings in Ångstroms. sm=smectite; $\mathrm{ch}=\mathrm{chlorite;} \mathrm{ill=illite;} \mathrm{ka=kaoli-}$ nite; $\mathrm{qt}=$ quartz; $\mathrm{ze}=\mathrm{zeolite}$;d=feldspar; $\mathrm{ksp}=$ =potassium feldspar; $\mathrm{pl}=$ lagioclase feldspar. a. Sample MTD42 is an example of

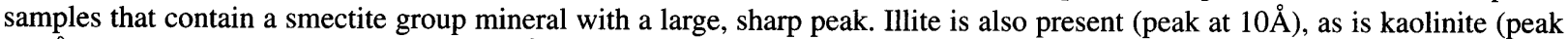
at $7 \AA$ ) and quartz (peaks at 3.33 and $4.26 \AA$ ). b. Sample E363 is an example of samples that contain a smectite group mineral with a small but sharp peak. Chlorite is present (peaks at 14,7 and $4.7 \AA$ ), as is $R=1 \mathrm{I} / \mathrm{S}$ (peak near $13 \AA$ ), illite (peak at $10 \AA$ ), quartz (peaks at 3.34 and $4.26 \AA$ ), plagioclase (peak at 3.19 $)$ ), and opal-CT (broad area from 20 to $25^{\circ} 2$, with peak at $4.1 \AA$ ). A zeolite (clinoptilolite-heulandite ) occurs at $9 \AA$. c. Sample MB217A contains a smectite group mineral with a small but sharp peak near $17 \AA$, chlorite with a peak at $14 \AA, R=1 \mathrm{I} / \mathrm{S}$ with a peak near $12 \AA$, a zeolite with a peak near $9 \AA$, and amphibole, with a sharp peak near $8.5 \AA$. d. Sample MB202 is an example of samples that contain a smectite group mineral with a small, broad peak near $17 \AA$. Kaolinite is present (peak at $7 \AA$; no 14 or $4.79 \AA$ peak), as is quartz (peaks at 3.33 and $4.26 \AA$ ), potassium feldspar

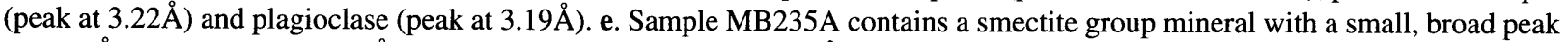
near $17 \AA$, chlorite (peak at $14 \AA$ ), $R=3 \mathrm{I} / \mathrm{S}$ clay (shoulder on the $10 \AA$ peak), quartz and plagioclase.

trying to decipher paleoclimate. However, chlorite generally does not survive cool, moist temperate or more intense weathering regimes, and its presence in sediment as a detrital clay is a good indicator of cool and/or dry climates. Smectite group minerals may indicate monsoonal climates, which, with their alternating wet and dry seasons, promote the formation of this alternately expanded and contracted mineral [Chamley, 1989; Millot, 1970].
Smectite may also indicate the presence of volcaniclastic input such as ash; [Nadeau and Reynolds, 1981] or a basaltic terrain subjected to temperate weathering conditions. Smectite group minerals may concentrate in offshore (outer shelf or farther) marine conditions, due to pericontinental fractionation of clays [Porrenga, 1966; Gibbs, 1977; Holmes, 1987]. Kaolinite may indicate moist and temperate to tropical weathering conditions. 


\begin{tabular}{|c|c|c|c|c|c|c|}
\hline & \multicolumn{2}{|c|}{ Group A } & \multicolumn{2}{|c|}{ Group B } & \multirow{2}{*}{$\begin{array}{c}\text { Student's } \\
\mathbf{t} \\
\end{array}$} & \multirow[t]{2}{*}{$\mathrm{C}$} \\
\hline & mean & s.d. & mean & s.d. & & \\
\hline smectite group & 76.9 & 11.9 & 20.4 & 17.6 & -8.357 & 0.01 \\
\hline $\mathrm{R}=1 \mathrm{l} / \mathrm{S}$ & 0.7 & 2.0 & 7.5 & 8.9 & 2.246 & 0.05 \\
\hline $\mathrm{R}=3 \mathrm{I} / \mathrm{S}$ & 1.1 & 3.3 & 4.2 & 10.7 & 0.844 & \\
\hline chlorite & 2.2 & 4.4 & 9.8 & 10.1 & 2.091 & 0.05 \\
\hline illite & 15.3 & 12.6 & 57.5 & 17.1 & 6.284 & 0.01 \\
\hline kaolinite & 3.8 & 3.7 & 0.8 & 1.5 & -2.643 & 0.05 \\
\hline $\mathrm{n}$ & 9 & & 13 & & & \\
\hline
\end{tabular}

This mineral can survive at least moderate weathering, and its presence in sediment may also derive from older sediment. Illite derives from moderate to no weathering of ancient shales. Smectite group minerals decrease in older shales, presumably due to their alteration to illite during diagenesis, and illite levels increase as age of shales increases [Weaver, 1967].

Illite generally forms by a stepwise alteration of smectite group minerals, providing potassium is available, that is observable by $\mathrm{x}$-ray diffraction [e.g., Reynolds, 1980; Pollastro, 1993]. In the first stages of diagenesis, the smectite group 001 peak at $17 \AA$ expands less while other peaks shift to larger d-spacings. Such a diffraction pattern indicates a randomly interstratified mixed-layer illite/smectite clay [designated $\mathrm{R}=0 \mathrm{I} / \mathrm{S}$ clay; " $R$ " is for "Reichweite" or ordering; Reynolds, 1980]. In later stages and/or at higher temperatures, the illite interstratification appears to become ordered, which produces a characteristic $\mathrm{X}$-ray pattern with the $17 \AA$ peak replaced by a peak at around $13 \AA$. This clay is designated $R=1 \mathrm{I} / \mathrm{S}$ clay. At still later stages, interstratification appears to be so extensive that only a slight expansion of a $10 \AA$ mineral is detected as a shoulder on the $10 \AA$ peak or a peak at $11 \AA$. This mineral is designated $\mathrm{R}=3 \mathrm{I} / \mathrm{S}$ clay. The survival of the I/S clays in the weathering environment is not well constrained, and I/S clay that is identified in modern soils may be entirely inherited from the parent material [Wilson and Nadeau, 1985].

The four erratics which contain sharp smectite group minerals, E219, E317, MB181, and MTD42, do not contain volcanic ash and do not appear authigenic [Levy and Harwood, this volume]. These highly crystalline minerals must have formed by chemical weathering in a temperate or monsoonal climate. The weathering environment was too intense to preserve chlorite (0-10\% in these samples) but was not intense enough to generate much kaolinite (3-
$4 \%$ in these samples). These erratics were collected from areas that today have exposed Jurassic age Ferrar Dolerite [Levy and Harwood, this volume]. Mafic rocks weather readily to smectites. The Ferrar Dolerite may have been the source that was moderately weathered to generate these highly crystalline smectite group minerals. Ehrmann [1996] arrived at a similar conclusion to account for abundant smectite in sediment at the base of the CIROS- 1 and -2 , and MSSTS- 1 cores, which were drilled in McMurdo Sound, downstream of the area where these erratics were collected. The depositional environments for the sediment in these erratics ranges from marginal marine to fully marine [Levy and Harwood, this volume].

These samples fall in with the group of samples that contain more than $60 \%$ smectite group minerals, based on the results of principal components analysis (Figure 2). This group (designated Group A), has a fairly consistent mineral composition that is dominated by smectite group minerals, followed by minor illite, and has higher kaolinite levels than the erratics not in this group (Table 4). A common mineral composition suggests that these erratics all derive from the same or similar terrains and formed under similar climatic conditions, but at least two of the erratics are distinct from the group: MB202 and SV12. These are a tuff and a volcaniclastic conglomerate, respectively, both barren of fossils [Levy and Harwood, this volume]. Thus high smectite levels in the erratics arise from either demonstrated volcaniclastic input (MB202 and SV12) or from chemical weathering. All nonvolcaniclastic erratics in Group A are middle to upper Eocene in age (Figure 3).

The other group of erratics, designated Group B, has widely variable mineral compositions that almost certainly derive from more than one terrain. Group B erratics tend to be dominated by illite, and contain significantly higher levels of chlorite and $\mathrm{R}=3 \mathrm{I} / \mathrm{S}$ clays. This type of assemblage might be expected in sediment derived by physical weathering, with little or no chemical weathering. As these erratics are sediments, not metamorphic rocks, the presence of chlorite indicates that they have undergone little chemical weathering during their formation. High levels of chlorite in samples E323, E242D, MB212K, E243, and SIM5 suggest that these erratics may be derived from a metamorphic terrain. Six samples with chlorite also contain $R=1 \mathrm{I} / \mathrm{S}$ clay, indicating that the $\mathrm{R}=1 \mathrm{I} / \mathrm{S}$ supply, probably an ancient (Paleozoic or older) sedimentary terrain, and the chlorite supply were linked, either geographically or by transport mechanism, during deposition of the sediment in these erratics. None of the samples contain both an $\mathrm{R}=1 \mathrm{I} / \mathrm{S}$ and an $\mathrm{R}=3 \mathrm{I} / \mathrm{S}$ clay component, which suggests 


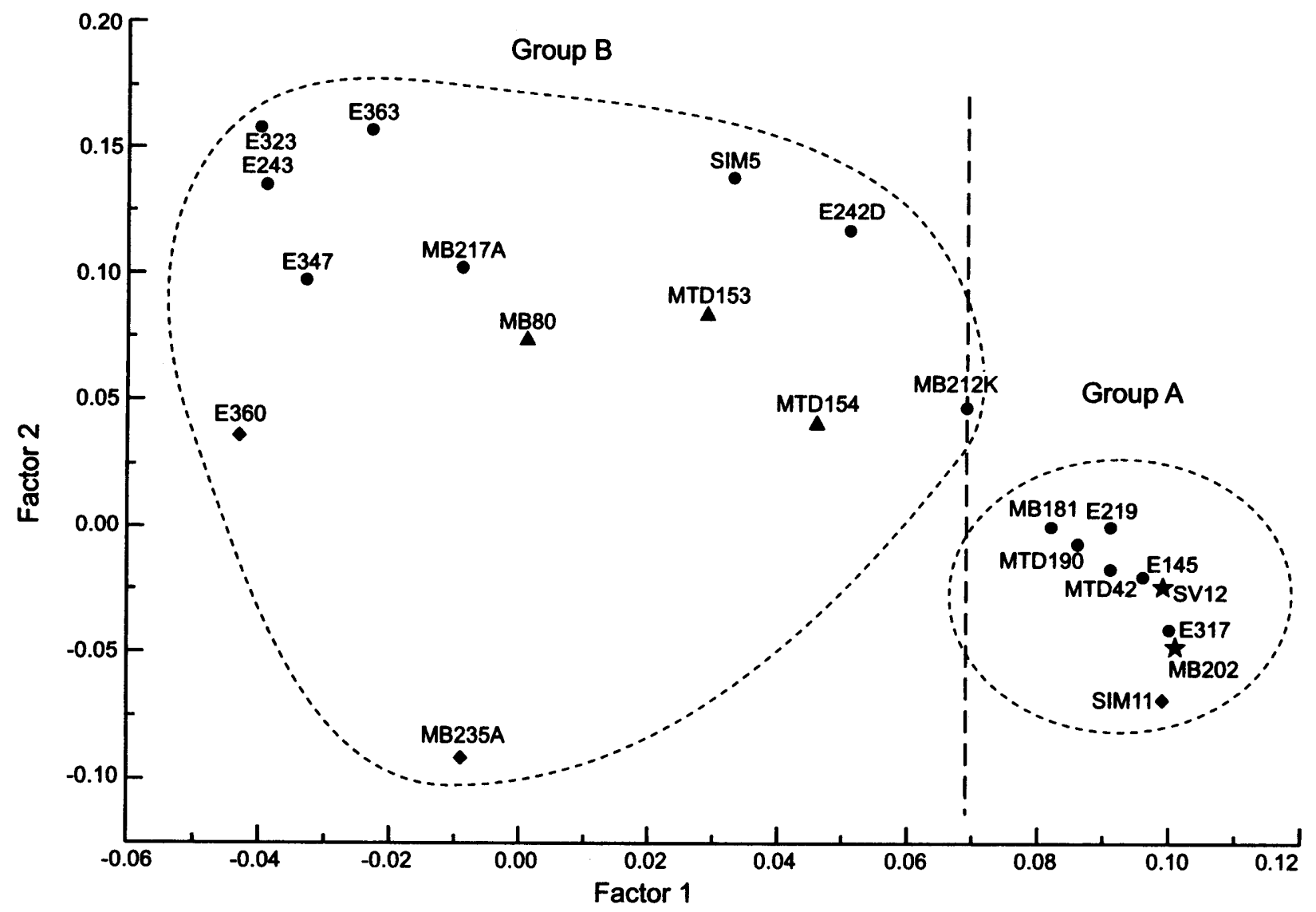

Figure 2. Results of principal components analysis (PCA) on the semi-quantitative results for the clay minerals given in Table 2, indicating how samples plot in Factor 1/Factor 2 space. The dotted line is the " $50 \%$ smectite" line. Samples with $>50 \%$ smectite group together ('Group A') and have a significantly different mineral composition from the other samples ('Group B'). The starred samples in Group A are undated volcaniclastic sediment. The triangles in Group B are middle to upper Eocene in age; all other samples are post-Eocene or undated. The diamonds are samples with $\mathrm{R}=3 \mathrm{I} / \mathrm{S}$ clay.

that the terrains supplying these clays are distinct.

All but three of the thirteen samples in this group are post-Eocene age or were not datable because of a lack of fossils [Figure 3; Levy and Harwood, this volume]. Seven of nine Group A samples are Eocene age and two in this group are volcaniclastic and contain no fossils. From these results it appears that chemical weathering declined after the Eocene in east Antarctica. These results agree with those of Ehrmann [1996] from the CIROS-1 and -2 cores, the MSSTS cores drilled in McMurdo Sound, and with results of studies by Robert and Maillot [1990] on clays from cores from the Weddell Sea, that the Eocene-Oligocene climate shift in Antarctica, from a non-glacial to a glacial one, is reflected in the clay mineral composition of marine sediments as a shift from smectite to chlorite dominance.

Three samples of middle to upper Eocene age occur in Group B, MB80, MTD153, and MTD154. These samples contain large amounts of illite (52 to $75 \%$ ) and low levels of smectite group minerals ( 25 to $44 \%$ ), and also have more species of dinoflagellates (6 to 22) than other members of Group B, which have 0 or 1 species. These three samples contain no chlorite and are all sandstones. They may have been deposited in an area with a dominant illite supply, with smectite limiting, either because it did not occur in abundance in the source area, or because it was bypassing the depositional area. Alternatively, the sediment in these erratics may have been deposited during a cold snap when smectite generation was at an Eocene low. 


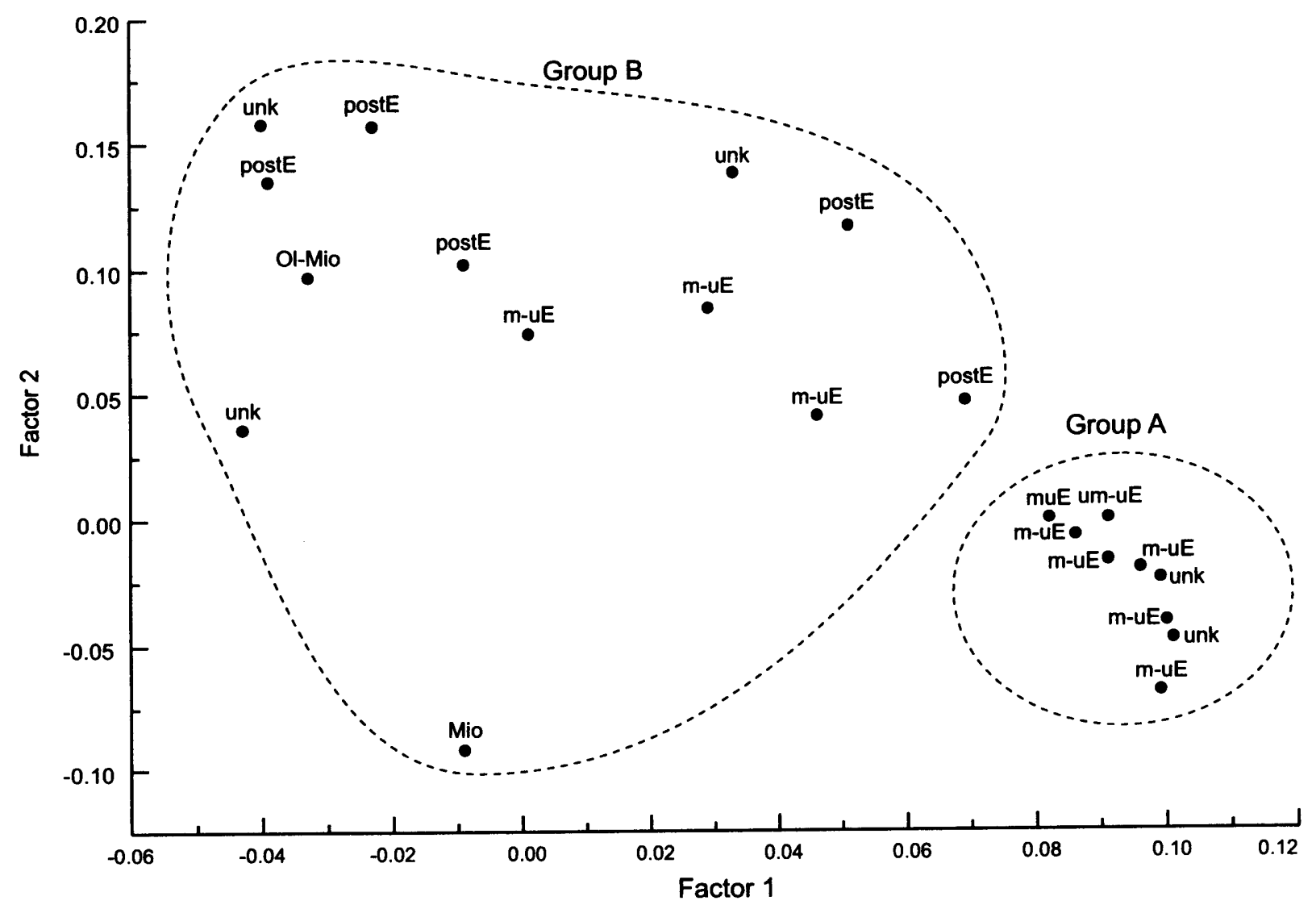

Figure 3. Results of PCA, as in Figure 2, indicating ages of erratics as determined by Levy and Harwood, and Bohaty and Harwood, this volume.

\section{CONCLUSIONS}

Varying mineral composition in the $<2 \mathrm{~m}$ fraction of the erratics divides them into two groups: A) erratics with dominant smectite group minerals, which may or may not be highly crystalline, and B) erratics with widely varying composition, but in general, with dominant illite and low levels $(<50 \%)$ of smectite group minerals. This latter group includes at least two types of erratics: those with abundant chlorite, often accompanied by $R=1 \mathrm{I} / \mathrm{S}$ clay, and those erratics with abundant $R=3 \mathrm{I} / \mathrm{S}$ clay. Most of the erratics in Group B are post Eocene in age, but three of them are Eocene. These three clasts are unusual in that, although formed during a relatively mild climatic period in East Antarctica's history, their mineral composition is dominated by illite rather than smectite. They contain no chlorite. The sediment in these samples may have accumulated nearshore, or may have had a provenance dominated by ancient sedimentary rocks rich in illite.
There are two types of Group A erratics: those that are middle to upper Eocene, and those that are volcaniclastic and barren of fossils. Conspicuously absent from any of the erratics is abundant kaolinite, even in erratics with abundant feldspars and granitic lithofragments. This suggests that even during the Eocene, climates were not particularly warm or wet, and that the Beacon Supergroup, which is kaolinite-rich [Ehrmann et al., 1992], did not contribute significantly to the clay fraction of these sediments.

McMurdo Sound erratics collected for this study that are Eocene age have at least two distinct provenances for the clay fraction: 1) a smectite-rich source area with minor illite, kaolinite, and no surviving chlorite (Group A samples), and 2) an illite-rich source area with subordinate smectite, minor kaolinite, and no surviving chlorite (Group B samples). Post Eocene age erratics have a clay fraction from at least two source areas: 1) a metamorphic + ancient sedimentary terrain that supplied chlorite and 
$\mathrm{R}=1 \mathrm{I} / \mathrm{S}$ clay and illite, and 2) an ancient sedimentary terrain that supplied $R=3 \mathrm{I} / \mathrm{S}$ clay and illite. Smectite-rich volcaniclastics of unknown age comprise a fifth type of erratic.

Acknowledgments. Thanks to Steve Bohaty, David Watkins, Jiang (Mr. Asia), Richard Graham, Aradhna Srivastav, John Kaser, Diane Winter, and David Harwood for collecting the samples, and to David and Richard for 'letting' me work on them as a sort of unfunded mandate. Special thanks and an SPF 30 salute to Ms. Kelly Bergmann, for sample preparation and $\mathrm{X}$-ray analysis.

\section{REFERENCES}

Biscaye, P. E.

1964 Distinction between kaolinite and chlorite in recent sediments by X-ray diffraction. Amer. Miner., 49, 1281-1289.

1965 Mineralogy and sedimentation of Recent deepsea clay in the Atlantic Ocean and adjacent seas and oceans. Geol. Soc. Amer. Bull., 76, 803-832.

Borg, I. Y., and D. K Smith

1969 Calculated x-ray powder patterns for silicate minerals. Geol. Soc. of Amer. Memoir, 122. Boulder, $\mathrm{CO}$.

Brown, G.

1980 Associated minerals, in Crystal Structures of Clay Minerals and Their X-ray Identification, edited by G. W. Brindley and G. Brown, 361410, Mineral. Soc. Monogr:, 5, London.

Chamley, $\mathrm{H}$.

1989 Clay Sedimentology. Berlin, Springer-Verlag, Stuttgart, pp. 117-131.

Drever, J.I.

1973. The preparation of oriented clay mineral specimens for X-ray diffraction analysis by a filtermembrane peel technique. Amer. Mineral., 58:553-554.

Ehrmann, W. U.

1996 Smectite concentrations and crystallinities: Indications for Eocene age of glaciomarine sediments in the CIROS-1 drill hole, McMurdo Sound, Antarctica. Ant. Geol. Geophys., 1-10.

Ehrmann, W. U., Melles, M., Kuhn, G., and Grobe, H.

1992 Significance of clay mineral assemblages in the Antarctic Ocean. Marine Geol., 107:249-273.

Gibbs, R. J.

1977 Clay mineral segregation in the marine environment. Jour. Sediment. Petrol., 47:237-243.

Heiden, K., and Holmes, M.A.

1998 Grain-size distribution and significance of clay and clay-sized minerals in Eocene to Holocene age sediments from Sites 918 and 919 in the Irminger Basin. ODP Sci. Results, 152:39-49.

Holmes, M. A.

1987 Clay mineralogy of the Lower Cretaceous deepsea fan, deep sea drilling project site 603 , lower continental rise of North Carolina. Init. Repts., DSDP, 92:1079-1089 (U.S. Govt. Printing Office, Washington).

Jackson, M.L.

1975 Soil Chemical Analysis-Advanced Course (2nd ed.): Madison, WI. (M.L. Jackson), 27-95.

Jones, J. B., and Segnit, E. R.

1971 The nature of opal. I. Nomenclature and constituent phases. Jour. Geol. Soc. Aust., 18:57-68.

Kastner, M., Keene, J. B., and Gieskes, J. M.

1977 Diagenesis of siliceous oozes-I. Chemical controls on the rate of opal-A to opal-CT transformation-an experimental study. Geochim. et Cosmochim. Acta., 41:1041-1059.

Levy, R. H., and Harwood, D. M.

this volume. Sedimentary lithofacies and inferred depositional environments of the McMurdo Sound erratics.

Millot, G.

1970 Geology of Clays, (Farrand, W.R., and Paquet, H., trans.). Springer-Verlag, New York.

Moore, D.M., and Reynolds, R.C., Jr.

$1989 X$-ray Diffraction and the Identification and Analysis of Clay Minerals: Oxford (Oxford University Press).

Nadeau, P. H., and Reynolds, R. C., Jr.

1981 Volcanic components in pelitic sediments. Nature, 294:72-74.

Pollastro, R. M.

1993 Considerations and applications of the illite/smectite geothermometer in hydrocarbonbearing rocks of Miocene to Mississippian age. Clays Clay Minerals, 41:119-133.

Porrenga, D. H.

1966 Clay minerals in recent sediments of the Niger delta. Clays Clay Minerals, 14th natl. conf., Pergammon, Oxford, New York:221-233.

Reynolds, R. C., Jr.

1980 Interstratified clay minerals. In Brindley, G. W., and Brown, G., (eds.), Crystal Structures of Clay Minerals and Their X-Ray Identification: Monograph No. 5, Mineralogical Society, London, 249-303.

Robert, C., and Maillot, $\mathrm{H}$

1990 Paleoenvironments in the Weddell Sea area and Antarctic climates as deduced from clay mineral associations and geochemical data, ODP Leg 113. In Barker, P. F., Kennett, J. P., et al. (eds.), Proc. ODP, Sci. Res., 113:51-70. College Station, TX. 
Srodon, J.

1980 Precise identification of illite/smectite interstratifications by X-ray powder diffraction. Clays Clay Minerals, 28:401-411.

Weaver, C. E.

1967 Potassium, illite and the ocean. Geochim Cosmochim. Acta, 31:2181-2196.

Wilson, M. D., and E. D. Pittman

1977 Authigenic clays in sandstones: recognition and influence on reservoir properties and paleoenvironmental analysis. Jour. Sed. Petrol., 47, 3-31.
Wilson, M. J., and Nadeau, P. H.

1985 Interstratified clay minerals and weathering processes. In Drever, J. I. (ed.), The Chemistry of Weathering. De. Reidel, Dordrecht, Netherlands, pp. 97-118.

Mary Anne Holmes, 214 Bessey Hall, Department of Geosciences, Univ. of Nebraska-Lincoln, Lincoln, NE 685880340 